\title{
Zonal Distribution of Aquatic Macrophytes in the Littoral Zone of Edosaki-iri Bay in Lake Kasumigaura, Japan
}

\author{
Takayoshi Tsuchiya, Seiichi Nohara and Toshio Iwakuma
}

\begin{abstract}
Zonal distribution of aquatic macrophytes was investigated in the littoral zone of Edosaki-iri Bay in Lake Kasumigaura. Muddy sediment with litter was deposited on the sandy bed near the shore line. In the emergent plant zone, Phragmites australis (Cav.) Trin. ex Steud. tended to dominate near the shore line, but was successively replaced by Zizania latifolia Turcz. and Typha angustifolia L. toward the deeper sites. The emergent plants were distributed on the shelf to a depth of $80 \mathrm{~cm}$, while a floatingleaved plant, Nymphoides peltata (Gmel.) O. Kuntze, occupied lakewards on the steeper slope from depths of 60 to $200 \mathrm{~cm}$. Distribution of each species along the water depth gradient overlapped. The zonation of emergent plants was more associated with depth to sandy sediment surface than that with water depth and that with the thickness of muddy sediment.
\end{abstract}

Key words: Nymphoides peltata; Phragmites australis; Typha angustifolia; Zizania latifolia; zonal distribution

\section{Introduction}

Zonal distribution of aquatic macrophytes along a shoreline has been related to water depth, light penetration, sediment characteristics, wind and wave exposure and interspecific competition (Spence, 1967; Hutchinson, 1975; Grace and WeTzel, 1982; SNow and VinCE, 1984; WiLson and Keddy, 1985; Wisheu and KedDY, 1988; BERTNEss, 1991). However, studies of the zonal distribution in Japan are very scarce (Nakano, 1911; Hogetsu, 1948; Yamasaki, 1981, 1984, 1987, 1990; YamasaKI and TANGE, 1981; Sastroutomo, 1982). All the latter studies were conducted in small eutrophic lakes where muddy sediment deposits, so that data is lacking for large lakes with sandy basins.

Lake Kasumigaura is one of the largest lakes in Japan with an area of $171 \mathrm{~km}^{2}$ and average water depth of only $4 \mathrm{~m}$. This lake is highly eutrophicated with muddy sediment deposits in sheltered inlets. In the main basin, on the other hand, a sandy shelf extends where wind and wave exposure are relatively high. Sakurai (1981) reported that species composition of aquatic macrophytes differed between the exposed main basin and the sheltered subbasins or inlets. At highly exposed sites only Phragmites australis (Cav.) Trin. ex Steud. was observed, while in sheltered sites other aquatic and wetland species were found. The precise zonal profile of macrophyte vegetation along the shore line is unknown in this lake. In the present study we attempt to determine the zonal distribution pattern at an relatively exposed site.

\section{Study site}

The study site is located at the inlet of Edosaki-iri Bay, south of the main basin of Lake Kasumigaura (Tsuchry et al., 1990). Vegetation is relatively well conserved at this site. The Ono-gawa River discharges comparatively nutrient-rich water with suspended substances into the bay. However, the lake bed at the study site consists of sand or fine sand because 
of relatively high wind exposure, i.e., high wind speed and in conjunction with coastal water current velocity. Biomass of floating-leaved plants is less than that at other sites in the lake (TsuchiYa et al., 1990). Mud and litter accumulate along the shoreline sheltered from wave action.

Seasonal changes in solar radiation, water temperature, water chemistry and productivity of epiphytic and planktonic algae were reported by TaKamura et al., (1990). Water level in Lake Kasumigaura fluctuated seasonally within a range of $40 \mathrm{~cm}$ in 1984, reaching its low in spring and fall and its maximum in July just after the rainy season (NohARA and TsuchiyA, 1990).

\section{Methods}

Ten $100 \mathrm{~m}$ transect lines, spaced $10 \mathrm{~m}$ apart, were extended westward from the shore. In this area, 200 experimental points were marked at $5 \mathrm{~m}$ intervals along the transect. Microtopography was conducted using a scaled stick on March 12, 1985. Water depth (surface depth of muddy or sandy sediment) at every marked point was measured by placing the stick on the sediment surface. By inserting the stick further into sediment we measured thickness of the mud layer with litter on the sandy bed. Depth to the sandy surface is equal to the water depth plus the thickness of the mud layer. Coverage of emergent plant species in a $2 \mathrm{~m} \times 2 \mathrm{~m}$ ground area was recorded in every $10 \%$ at the 200 marked points. Since floating-leaved plants had not reached water surface in March, we used coverage data from August 1984.

\section{Results}

Fig. 1 shows microtopography expressed as depth to the sandy sediment surface at the study site. A sandy shelf facing northeast with a gentle, somewhat wavy slope extends out to about $80 \mathrm{~cm}$ in water depth, beyond which a relatively steep slope continues lakeward. Mud and litter are deposited thickly on a hollow slope nearest to the shoreline to create a smooth sediment surface.

Distribution of dominant macrophytes with microtopography of water depth (depth to sediment surface) is shown in Fig. 2. An emergent plant zone about $50 \mathrm{~m}$ wide along the shoreline was dominated by a mixed vegetation of Phragmites australis (Cav.) Trin. ex Steud., Zizania latifolia Turcz., and Typha angustifolia L. P. australis occurred at the landward sites and was successively replaced by $Z$. latifolia and $T$. angustifolia towards deeper sites. At the lakeward edge of the emergent plant zone, $T$.

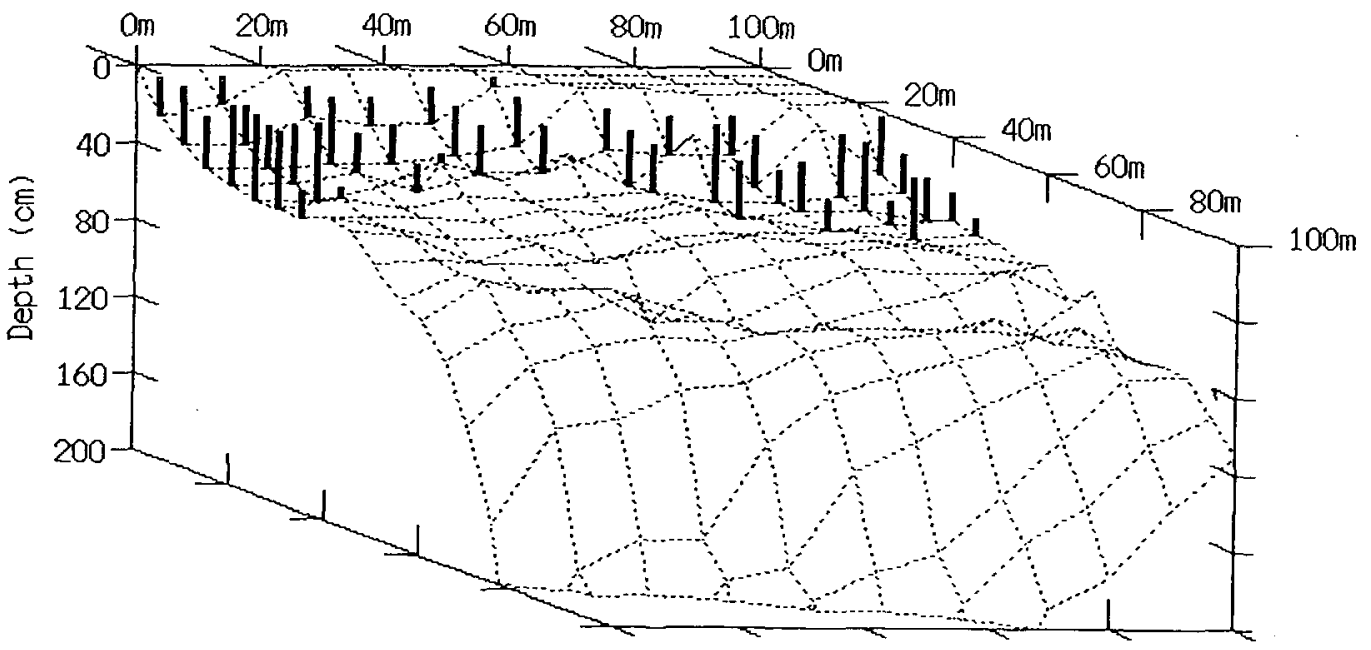

Fig. 1. Microtopography of study site in depth to sandy sediment surface viewed from pelagic site. Vertical bars show thickness of mud deposited on sand. Water depth at each point expressed as annual mean value. 

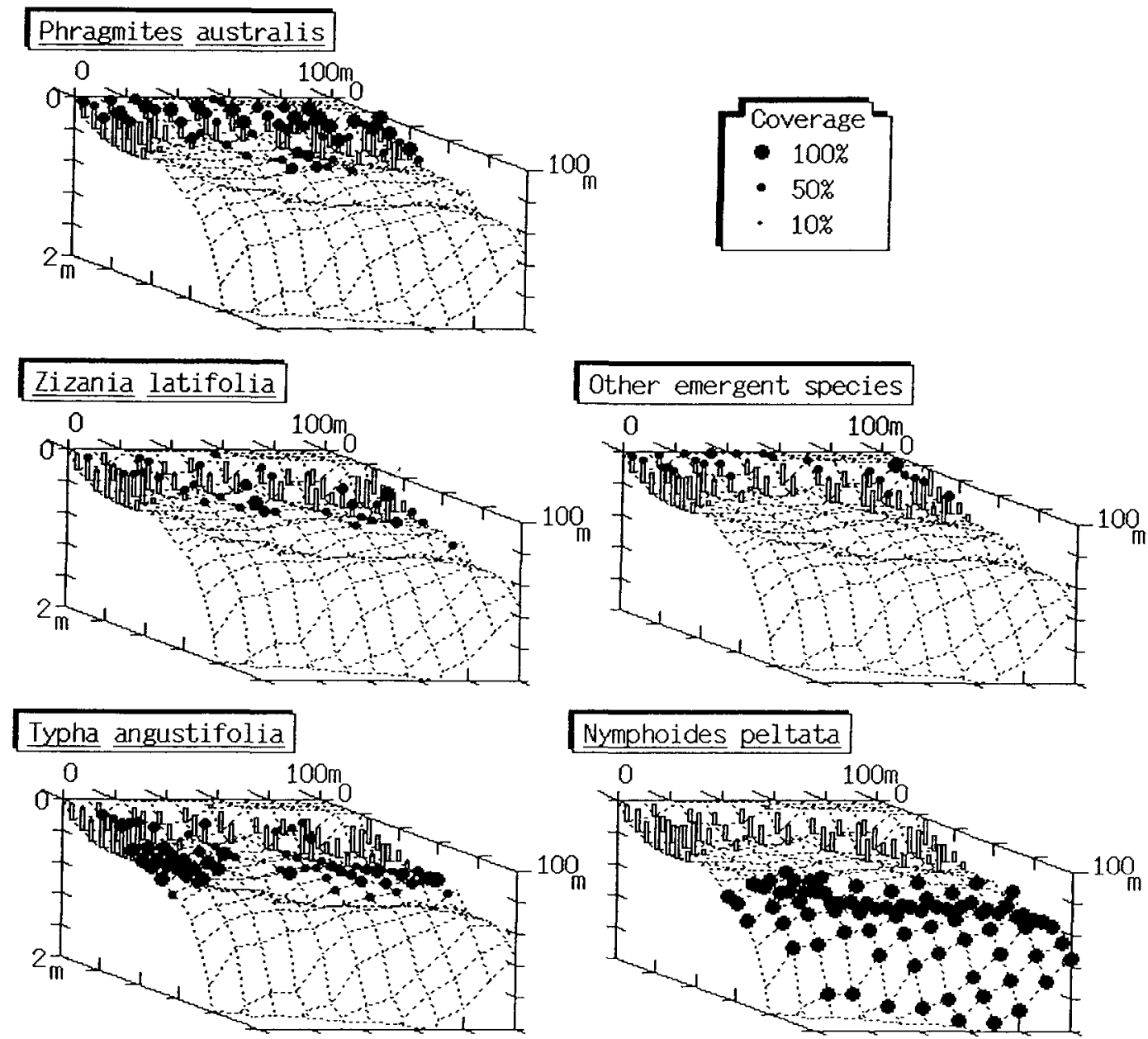

Nymphoides peltata

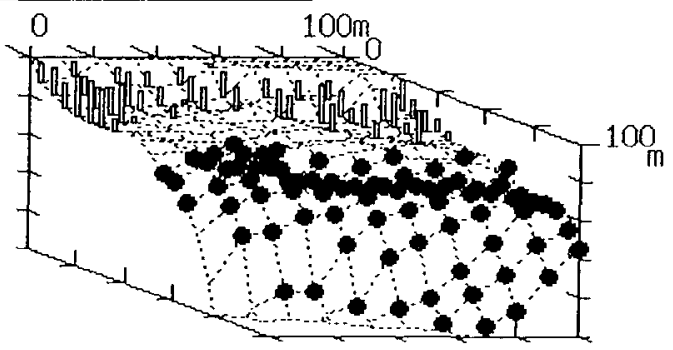

Fig. 2. Distribution of emergent plants (Phragmites australis, Zizania latifolia, Typha angustifolia and other species) and floating-leaved plant (Nymphoides peltata) with topography viewed from a pelagic site. Coverage of each species shown by diameter of solid circle. Vertical bars show thickness of mud deposited on sand.

angustifolia occurred almost exclusively. At landward sites we observed other emergent species including wetland plants, Polygonum lapathifolium L., Polygonum thunbergii Sieb. et Zucc., Cicuta virosa L., Lycopus lucidus Turcz., Paspalum distichum L. and Iris pseudacorus L.. Only a minor fraction of coverage was occupied by free-floating species, Lemna spp., and detached macrophytes, $e$. g. Nymphoides peltata (Gmel.) O. Kuntze and Egeria densa Planch., which were observed under the canopy of emergent plants.

$N$. peltata dominated almost exclusively on the steep lakeward slope, while we found very low coverage of Trapa natans L. and several submerged species, Potamogeton malaianus Miq., Potamogeton crispus L., Potamogeton pectinatus L., Potamogeton maackianus A. Benn., and Vallisneria asiatica Miki. No submerged vegetation was found beyond the floatingleaved vegetation zone extending to a water depth of $200 \mathrm{~cm}$.

Occurrence of dominant species seemed to depend on water depth (Fig. 3). Emergent plants were distributed on the shelf at depth shallower than $80 \mathrm{~cm}$, while $N$. peltata occurred on the steeper slope from 60 to $200 \mathrm{~cm}$ in depth. Among emergent plants $P$. australis usually 

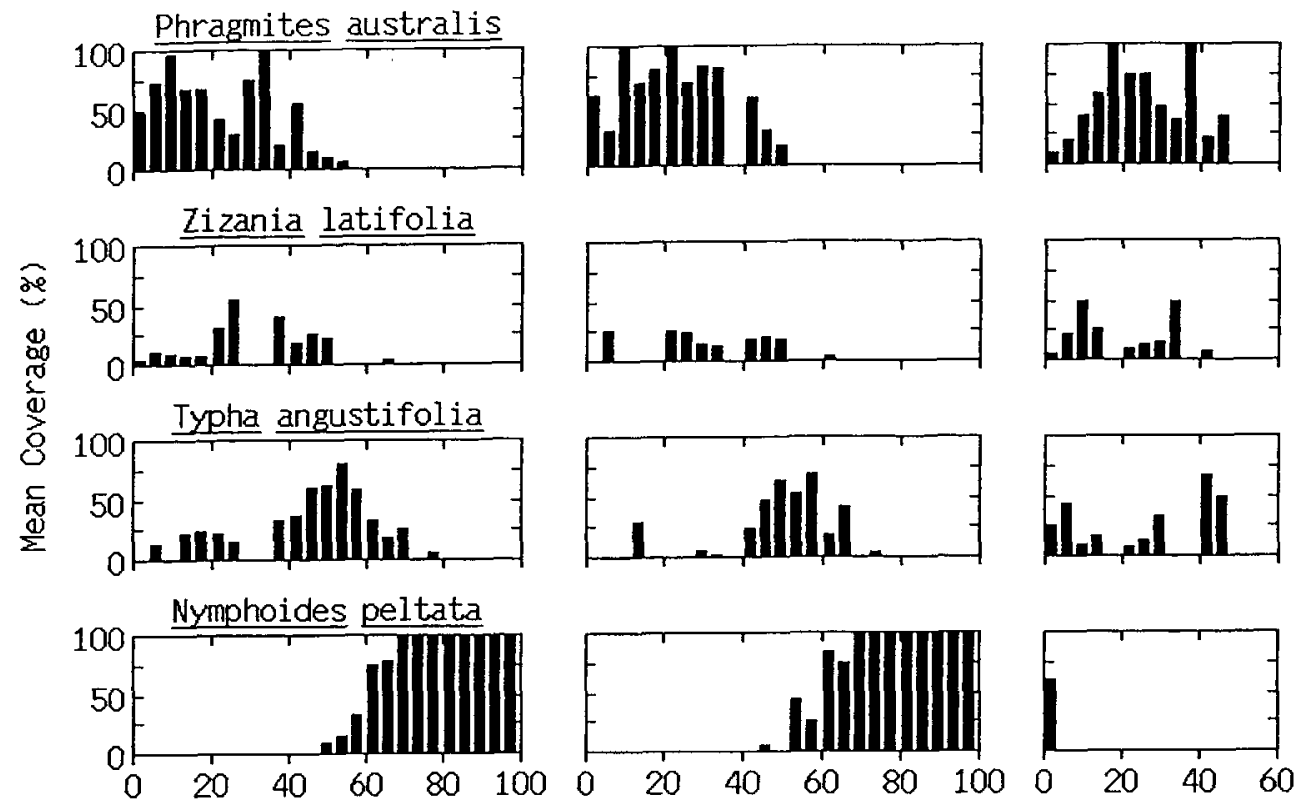

Water depth $(\mathrm{cm})$

Depth to sandy surface $(\mathrm{cm})$ Mud thickness $(\mathrm{cm})$

Fig. 3. Mean coverage of Phragmites australis (top), Zizania latifolia, Typha angustifolia and Nymphoides peltata (bottom) with water depth (left), depth to sandy surface (middle) and mud thickness (right).

occurred at the shallowest sites. As a rule, $Z$. latifolia was observed at the middle depth and $T$. angustifolia dominated the deepest sites. However, their distributions along the water depth overlapped considerably and the boundary water depth of $T$. angustifolia was uncertain.

Distribution of emergent species was more closely associated with depth to sandy sediment surface than that with water depth (Fig. 3). The distribution range of $T$. angustifolia in depth to sandy surface was much narrower than that in water depth. $T$. angustifolia was distributed from 40 to $70 \mathrm{~cm}$ in the depth to sandy surface, while $P$. australis and $Z$. latifolia were found frequently at sites shallower than $50 \mathrm{~cm}$. The depth to sandy sediment surface could not also completely account for the difference in distribution of $P$. australis, $Z$. latifolia and $T$. angustifolia, while $N$. peltata was found exclusively in sandy sites.

\section{Discussion}

At Edosaki-iri Bay $P$. australis occurred at shallower sites than $Z$. latifolia, though their precise zonal distribution boundary is not clear. This zonal pattern is consistent with other reports in relatively small Japanese eutrophic ponds (NaKano, 1911; Hogetsu, 1948; Yamasaki and TANGe, 1981; Sastroutomo, 1982). $Z$. latifolia, though it had a lower growth rate at shallow sites than $P$. australis, can be distributed at deeper sites (Yamasaki and Tange, 1981) because it can supply oxygen to its roots and rhizomes more abundantly (YAMASAKI, 1984, 1987). Z. latifolia has been reported to grow even at depths of $1.5-1.7 \mathrm{~m}$ in a small pond, Tega-Numa (Nakano, 1911; Hogetsu, 1948), while its lower boundary was only $70 \mathrm{~cm}$ at Edosaki-iri Bay. This may be due to differences in wind and wave exposure.

In contrast to $P$. australis and $T$. angustifolia which uses stout vertical aerial stems and rhizomes to anchor itself in sandy sediment, $Z$. latifolia can be easily damaged by wind and wave action due to its compressed internodes and linear elongated rosette leaves. Moreover $Z$. latifolia has roots and rhizome are most 
prevalent in the surface layer of sediment (HogETsu, 1948) so that along lakeward boundary it often forms a floating mat with the litter. This mat can be easily washed away by wave action. Thus, the habitat of $Z$. latifolia may be restricted to relatively sheltered sites.

There have been a few observations associating $T$. angustifolia with $Z$. latifolia (ОкUDA, 1978). Sastroutomo (1982) reported that $Z$. latifolia flourished in silt and clay soil, while SнIмоDA (1985) related $T$. angustifolia with sandy and/or gravelly sediment. In Lake Kasumigaura $Z$. latifolia was often found on the muddy northwest shore, the most eutrophicated area in the lake. $T$. angustifolia, however, favored the less eutrophicated southern sandy shore exposed to wave action. (SakURAI, 1981). Miki (1927) reported that $T$. angustifolia grew in nutrient-poor sandy sediment better than $P$. australis and $Z$. latifolia while doing less well in nutrient-rich muddy sediment. The negative association between $T$. angustifolia and $Z$. latifolia seemed to be related to the sediment conditions, considering the relatively large scale of distribution. However, in a small local area such as Edosaki-iri Bay, vegetation was not firmly associated with the sediment characteristic.

Miki (1927) supposed that $T$. angustifolia invades first on bare sandy sediment just after a disturbance, with $P$. australis and $Z$. latifolia following and finally replacing it. $\mathrm{Co}^{-}$occurrence of $Z$. latifolia and $T$. angustifolia at Edosaki-iri Bay may be merely a transitional phase. The depth of sandy surface is thought to be related to previous water depth during to a period of high wind and wave exposure or just after a heavy disturbance. The accumulation of muddy sediment with litter along the shore line may not be a result rather than a cause of inhabiting of emergent plants. It is likely that the distribution of $T$. angustifolia in muddy sediment is a temporary phenomenon (TSUchiYa et al., in preparation).

\section{Acknowledgements}

We would like to thank Dr. H. Kunir (Shimane University) and Prof. Dr. I. Ikusima for reading and criticizing an early draft of the manuscript, and Mr. R. Ueno(National Institute for Environmental Studies) for his assistance in field measurements and his helpful discussions.

\section{摘要 \\ 霞ヶ浦・江戸崎入りにおける 水生大型植物の帯状分布}

霞ヶ浦・江戸崎入りの湖岸帯で水生大型植物の 带状分布と微地形を調查した。江戸崎入り底質は 砂であるが, 抽水植物群落の発達した湖岸では砂 質の基底の上に泥やリターの堆積がみられた。陸 側の水深 $80 \mathrm{~cm}$ 以浅には抽水植物（陸側からヨシ， マコモ，ヒメガマの順）が，水深 60 から $200 \mathrm{~cm}$ の 沖側には浮葉植物（アサザ）が分布していた。し かし, これらの帯状分布は, 水深や泥質層の厚さ よりも（泥質層をのぞいた）砂層までの深さと相 関が高かった。

\section{References}

BERTNESS, M. D. (1991): Zonation of Spartina patens and Spartina alterniflora in a New England salt marsh. Ecol., 72: 138-148.

GracE, J. B. and R. G. Wetzel (1982): Niche differentiation between two rhizomatous plant species: Typha latifolia and Typha angustifolia. Can. J. Bot., 60: 46-57.

Hogetsu, K. (1948): Conspectus of ecological study about the water plants of Teganuma. Bot. Mag. Tokyo, 61: 17-24 (In Japanese with Eng. lish abstract).

Hutchinson, G. E. (1975): A Treatise on Limnology. Vol. III Limnological Botany. John Wiley \& Sons, New York.

MIKI, S. (1927): Ecological studies on water plants in Ogura Pond. Kyoto Histri. Beutif. Sites Res. Rep., 8: 81-145 (In Japanese).

NAKANO, H. (1911): The vegetation of lakes and swamps in Japan. I. Teganuma (TegaSwamp). Bot, Mag. Tokyo, 25: 35-51.

NOHARA, S. and T. TSUChIYA (1990): Effect of water level fluctuation on growth of Nelumbo nucifera Gaertn. in Lake Kasumigaura, Japan. Ecol. Res., 5: 237-252.

OKUDA, S. (1978): Plant sociological studies on the vegetation of the alluvial plains in the Kanto district, central Japan. Bull. Inst. Environ. Sci. Tech., Yokohama Natl. Univ., 4: 43-112 (In Japanese with English and German abstract).

SAKURAI, Y. (1981): Changes of flora, vegetation 
area and biomass of aquatic plants in the recent progress of eutrophication in Lake Kasumigaura. Res. Rep. Natl. Inst. Environ. Stud., 22: 229-279 (In Japanese with English abstract).

SAStroutomo, S. S. (1982): Summer biomass of aquatic macrophytes in relation to sediment characteristics in Lake Aino-numa, Miyagi. Jpn. J. Ecol., 32: 45-56.

ShImODA, M. (1985): Phytosociological studies on the vegetation of irrigation ponds in the Saijo Basin, Hiroshima Prefecture, Japan. J. Sci. Hiroshima Univ., Ser. B., Div. 2, 19: 237-297.

SNOW, A. A. and S. W. VINCE (1984): Plant zonation in an Alaskan salt marsh. II. an experimental study of the role of edaphic conditions. J. Ecol., 72: 669-684.

SPENCE, D. H. N. (1967): Factors controlling the distribution of freshwater macrophytes with particular reference to the lochs of Scotland. J. Ecol., 56: 147-170.

Takamura, N., T. Iwakuma, M. AizAKI, and M. YASUNO (1990): Primary production of epiphytic algae and phytoplankton in the littoral zone of Lake Kasumigaura. Mar. Microb. Food Webs, 4: 239-255.

Tsuchiya, T., S. Nohara, and T. Iwakuma (1990): Net primary production of Nymphoides peltata (Gmel.) O. Kuntze growing on sandy sediment at Edosaki-iri Bay in Lake Kasumigaura, Japan. Jpn. J. Limnol., 51: 307-312.

Wilson, S. D. and P. A. KEDDY (1985): Plant zonation on a shoreline gradient: physiological response curves of component species. J. Ecol., 73: $851-860$
WisheU, I. C. and P. A. KEDDY (1988): Species richness-standing crop relationship along four lakeshore gradients: constraints on the general model. Can. J. Bot., 67: 1609-1617.

YAMASAKI, S. (1981): Effects of water level on the development of rhizomes of three hygrophytes. Jpn. J. Ecol., 31: 353-359.

YAMASAKI, S. (1984): Role of plant aeration in zonation of Zizania latifolia and Phragmites australis. Aquat. Bot., 18: 287-297.

YAMASAKI, S. (1987): Oxygen demand and supply in Zizania latifolia and Phragmites australis. Aquat. Bot., 29: 205-215.

YAMASAKI, S. (1990): Population dynamics in overlapping zones of Phragmites australis and Miscanthus sacchariflorus. Aquat. Bot., 36: 367377.

YAMASAKI, S. and I. TANGE (1981): Growth responses of Zizania latifolia, Phragmites australis and Miscanthus saccharifloms to varying inundation. Aquat. Bot., 10: 229-239.

(著者: 土谷岳令, 千葉大学理学部生物学教室, $\overline{\mathbf{T}}$ 263 千葉市稻毛区弥生町 1-33：野原精一，岩熊敏夫, 国立環境研究所生物圈瑨境部，テ 305 茨城県つくば市 小野川 16-2; Takayoshi TsuchiYA, Department of Biology, Faculty of Science, Chiba University, 1-33 Yayoi-cho, Inage-ku, Chiba 263; Seiichi NoHARA and Toshio Iwakuma, Environmental Biology Division, National Institute for Environmental Studies, 16-2 Onogawa, Tsukuba, Ibaraki 305)

Received: 10 August 1992 Accepted: 21 January 1993 